\title{
A methodological review of meditation research
}

\author{
John W. Thomas* and Marc Cohen \\ School of Health Sciences, RMIT University, Bundoora, VIC, Australia
}

Edited by:

Shirley Telles, Patanjali Research

Foundation, India

Reviewed by:

Oliver Grimm, Central Institute of Mental Health, Germany

Khemraj Hirani, University of Miami

Miller School of Medicine, USA

Meera Balasubramaniam, NYU

Langone Medical Center, USA

*Correspondence:

John W. Thomas, School of Health

Sciences, RMIT University, 8/393

Cambridge Street, Wembley, WA

6014, Australia

e-mail: johnthomas7@bigpond.com
Despite over 50 years of research into the states of consciousness induced by various meditation practices, no clear neurophysiological signatures of these states have been found. Much of this failure can be attributed to the narrow range of variables examined in most meditation studies, with the focus being restricted to a search for correlations between neurophysiological measures and particular practices, without documenting the content and context of these practices. We contend that more meaningful results can be obtained by expanding the methodological paradigm to include multiple domains including: the cultural setting ("the place"), the life situation of the meditator ("the person"), details of the particular meditation practice ('the practice'), and the state of consciousness of the meditator ("the phenomenology"). Inclusion of variables from all these domains will improve the ability to predict the psychophysiological variables ("the psychophysiology") associated with specific meditation states and thus explore the mysteries of human consciousness.

Keywords: meditation, consciousness, meditation states, methodology, subjective measures

\section{INTRODUCTION}

The term "meditation" refers to mental and emotional control practices from a number of cultural contexts including those of Christianity and Islam, yet is most frequently applied to those originating in the Eastern spiritual traditions of India, Tibet, China, and Japan. Meditation has been adopted in western countries both as a spiritual practice and a mind-body therapeutic intervention (1). The effects of meditation can be divided into - the lasting (therapeutic) changes in the person (traits) - and the immediate experiences during the meditation practice (states) (2). This review will focus on meditation states.

The states of consciousness induced by meditation practices have been extensively investigated from both a practical and a theoretical perspective. A practical question is: do meditation states have specific psycho-physiological characteristics that distinguish them from other mind-body therapeutic interventions, e.g., relaxation? $(3,4)$. As meditation practices were originally devised as a path to "higher consciousness," a more theoretical question is: do meditation practices induce specific states of (altered) consciousness, distinguishable from other states of consciousness such as sleep (5) or hypnosis? (6).

\section{THE PRACTICE OF MEDITATION}

Given the wide range of practices called "meditation," issues of definition continue to hamper research in this area, as predicted in an early review of the area (4). A recent review of Lutz et al. (7) suggests that the limited contributions made to date by neuroscientific studies of meditation can be attributed, in part, to differences in the studied meditative states (7).

In an extensive review of meditation practices in healthcare, the US Department of Health and Human Services found a definitive taxonomy of meditation practices was not possible due to the lack of specificity of the concept of meditation (8). An attempt to address this issue led to a generalized definition of meditation considered suitable for research purposes arising from the consensus of a panel of experts using Delphi method. Essential components of this definition were: (a) a defined technique, (b) logic relaxation, and (c) a self-induced state/mode. Non-essential but important components were: $(d)$ involve a state of psychophysical relaxation somewhere in the process, (d) use a self-focus skill or anchor, (e) involve an altered state/mode of consciousness, (f) be imbedded in a religious/spiritual/philosophical context or (g) involve an experience of mental silence (9). While encompassing most variations of meditation practices, this definition does not provide specific dimensions on which particular practices can be classified.

Rather than exploring correlations between EEG measures and a vaguely defined "meditation state," Ulrich Ott advocated that testable hypotheses be formulated, specifying the relationship of various cognitive processes to frequency and topographic EEG maps. This research agenda requires that meditation practices be more closely examined and that traditional instructions be expressed in the language of cognitive psychology (10). The most frequently used distinction for this purpose has been the focus of attention (4). Using this dimension, and based on traditional meditation texts and modern neuroscientific conceptions within the Buddhist tradition, Lutz et al. (11) proposed two broad categories for meditation practices: "focused attention" (FA) and "open monitoring" $(\mathrm{OM})$, from which operational definitions could be derived. The cognitive tasks associated with each category can then be related to neurophysiological activity and brain location and testable hypotheses derived.

\section{THE PSYCHOPHYSIOLOGY OF MEDITATION}

Although meditation is inherently a subjective practice (4), early calls for research studies to include phenomenological data (12) have largely gone unheeded. Fell et al. (13) attempted to answer the question: "are meditation-related brain/mind states unique?" based on an examination of existing evidence. They concluded that early stages of meditation may overlap with other states of consciousness, e.g., relaxation, but at advanced levels of practice, the 
states attained are unique. They note, however, there are, as yet, few empirical studies of advanced meditators and so any conclusions remain tentative.

Walsh (14) saw phenomenological changes in meditation states as the very raison d'etre for meditation and suggested two approaches - rating scales for groups of subjects and intensive single-case studies. However, few studies to date have included phenomenological data. The predominant research design has been within-subject comparisons of psycho-physiological measures from participants engaged in a particular meditation practice to measures taken in a baseline state.

Such studies have led to brain activity during meditation practice being extensively explored, with the EEG being the most commonly used technology before the advent of neuroimagery. In line with the western emphasis on "objective" measures, most reports devote the great majority of their content to the technical aspects of psycho-physiological data collection and analysis. Yet, after 50 years of this approach to scientific research into meditation, there is still no consensus about the neurophysiological processes underlying meditation practice (2).

\section{THE PHENOMENOLOGY OF MEDITATION - PLACE AND PERSON FACTORS}

We argue that the lack of clear research outcomes from such meditation research is attributable to methodological shortcomings in research design, a consequence of an emphasis on technological considerations and a neglect of critical subjective factors impacting on the meditation experience. For example, reporting of meditation experience may require a more detailed description of personal history than has been the norm in previous research. Place variables, such as the context within which classical meditation was developed and practiced may also effect the meditation experience yet are rarely reported in meditation research (15).

The physical setting for the recording session may further impact on the meditation state attained, affecting its "ecological validity." Factors affecting the meditation state may include whether the setting is a place usually used for meditation or a laboratory, the intrusiveness and discomfort of the psychophysiological measures, and the presence of others in the meditation space. Early field studies found even advanced Indian yoga meditators were disturbed by the apparatus and did not attain their usual depth of practice (16). Whether the meditation under study is embedded in its original cultural setting or transposed to a western setting may also influence the results.

\section{REVIEW OF MEDITATION RESEARCH}

In order to determine the extent and quality of previous meditation state research, we undertook a review of the meditation state literature incorporating EEG measures and attempted to classify the variables examined. This review was not intended to be an exhaustive review of meditation research, rather it was intended to illustrate the current state and direction of meditation research and highlight the main variables used. Our review began with the report of Cahn and Polich (2), a comprehensive review of meditation research undertaken to that date. This provided 35 EEG studies of meditation states. The U.S. National Library of Medicine service PubMed was then searched for studies using search terms "meditation state" AND "EEG" AND date of publication: "2006-2012." This returned 37 articles.

Studies were included if they were:

- experimental studies with subjects engaged in a specific meditation practice

- included outcome measures that included EEG recordings of the meditation state.

Excluded from the results were a total of 31 articles based on:

- included in initial list of Cahn and Polich: 2

- trait effects of meditation only: 13

- non-EEG studies: 4

- non-meditation studies: 7

- studies on EEG methodology: 3

- non-experimental studies: 2 .

After these exclusion criteria were applied, six articles were added to the present review.

The variables used in the studies were assigned on the basis of reported information into the domains of:

- person - characteristics of the meditator

- practice - nature of the specific meditation practice

- place - variables of the experimental situation

- phenomenology - subjective experiences of the meditator

- physiology - EEG measures of the meditation state.

\section{RESULTS}

Tables 2 and 3 summarizes the domains of "Practice," "Phenomenology," and "Psychophysiology" for studies from Table 1 that provided a sufficiently detailed description of the meditation practice to enable categorization as either "FA" or "OM."

Responding to the categories proposed by Lutz et al. (11), Travis and Shear (63) proposed a third category of "automatic self-transcending," marked by the "absence of both (a) focus and (b) individual control or effort" (p2), particularly applicable to “Transcendental Meditation" (TM).

\section{RESULTS/DISCUSSION}

\section{"PLACE" VARIABLES}

"Place" encompasses those variables defining the broad context for the experimental study. Table 1 shows that early studies in the 1960s were conducted in field settings in countries of origin of the meditation tradition studied. The 1970s and 1980s were dominated by studies conducted in USA of Transcendental Meditation, a westernized yoga practice. More recent studies have taken advantage of the increased access in western countries to meditators trained within original eastern meditation traditions. Yet, it is suggested that even our ordinary state of consciousness is in part a product of consensus reality, structured by our cultural context and that the process of "enculturation" during childhood development shapes our experience of consciousness (64). Thus, the cultural history of meditation tradition and practice within a particular society may determine the broad range of experiences available to meditators. This aspect of meditation research has yet to be explored and to our knowledge 
Table 1 | Context for meditation studies - place and person.

\section{Study}

\begin{tabular}{lc}
\cline { 2 - 2 } & \multicolumn{1}{c}{$\begin{array}{c}\text { Original } \\
\text { culture }\end{array}$} \\
\hline Das and Gastaut (17) & Yoga - India \\
\hline Wenger and Bagchi (16) & Yoga - India \\
\hline Anand (18) & Yoga - India \\
\hline Kasamatsu and Hirai (19) & Zen - Japan \\
\hline Wallace (20) & \\
\hline Banquet (21) & \\
\hline Pagano and Frumkin (22) & Ananda \\
\hline Ghista et al. (23) & Marga - India \\
\hline
\end{tabular}

Place

Transposed
tradition

Secular adaptation
Person

\begin{tabular}{cccc}
\hline Novice & STM & LTM & Adv \\
$(<1$ year $)$ & $(1-5$ year $)$ & $(5-20$ year $)$ & $(>20$ year $)$
\end{tabular}

Bennett and Trinder (24)

Hebert and Lehmann (25)

Morse et al. (3)

Fenwick et al. (26)

Elson et al. (27)

Corby et al. (28)

Lehrer et al. (29)

Stigsby et al. (30)

Becker and Shapiro (31)

Dillbeck and Bronson (32)

Farrow and Hebert (33)

Badawi et al. (34)

Zhang et al. (35)

Gaylord et al. (36)

Benson et al. (37)

Pan et al. (38)

Travis and Wallace (39)

Dunn et al. (40)

Kamei (41)

Khare and Nigam (42)

Arambula et al. (43)

Litscher et al. (44)
TM - USA

TM - Switzerland
16

78
4

20

12

16

\section{5}

12

5

$$
\text { TM - USA }
$$

4


Table 1 | Continued

\begin{tabular}{|c|c|c|c|c|c|c|c|}
\hline \multirow[t]{2}{*}{ Study } & \multicolumn{3}{|c|}{ Place } & \multicolumn{4}{|c|}{ Person } \\
\hline & $\begin{array}{l}\text { Original } \\
\text { culture }\end{array}$ & $\begin{array}{l}\text { Transposed } \\
\text { tradition }\end{array}$ & $\begin{array}{c}\text { Secular } \\
\text { adaptation }\end{array}$ & $\begin{array}{l}\text { Novice } \\
\text { (<1 year) }\end{array}$ & $\begin{array}{c}\text { STM } \\
(1-5 \text { year })\end{array}$ & $\begin{array}{c}\text { LTM } \\
\text { (5-20 year) }\end{array}$ & $\begin{array}{c}\text { Adv } \\
(>20 \text { year })\end{array}$ \\
\hline Travis (45) & & TM - USA & & & 30 & & \\
\hline Lehmann et al. (46) & $\begin{array}{l}\text { Tibetan Buddhist } \\
\text { (Switzerland) }\end{array}$ & & & & & & 1 \\
\hline Ott (10) & & Yoga, TM - Germany & & & & 8 TM, 2 Yoga & \\
\hline $\begin{array}{l}\text { Aftanas and Golocheikine } \\
(47), \text { Aftanas and } \\
\text { Golocheikine }(48,49)\end{array}$ & & Sahaja Yoga - Russia & & 11 & 16 & & \\
\hline Lo et al. (50) & Zen - Taiwan & & & & & 2 & \\
\hline Lutz et al. (51) & $\begin{array}{c}\text { Tibetan Buddhist } \\
\text { (USA) }\end{array}$ & & & & & 8 & \\
\hline Faber (52) & Zen (Switzerland) & & & & & 1 & \\
\hline Murata et al. (53) & & & Zen Susoku (Japan) & 22 & & & \\
\hline Takahashi et al. (54) & & & Zen Susoku (Japan) & 20 & & & \\
\hline Hebert et al. (55) & & TM - USA & & & & & 15 \\
\hline Chan et al. (56) & TBRT - Hong Kong & & & 19 & & & \\
\hline $\begin{array}{l}\text { Beauregard and Paquette } \\
\text { (57) }\end{array}$ & Christian - Canada & & & & & 18 & \\
\hline
\end{tabular}

(57)

\begin{tabular}{lc}
\hline Huang and Lo (58) & Zen - Taiwan \\
\hline Lagopoulos et al. (59) & \\
\hline Cahn et al. (60) & \\
\hline Lehmann et al. (61) & Tibetan Buddhist, \\
& Qigong, Sahaja Yoga, \\
& Ananda Marga, Zen
\end{tabular}

Travis (62)

TM - USA

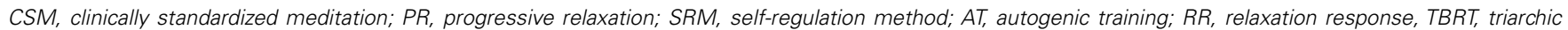
body-pathway relaxation technique.

there have been no comparisons of meditation states attained in different settings.

\section{"PERSON" VARIABLES}

This domain encompasses variables relating to the personal history and the nature of the meditation training of participants. Apart from the extensive work conducted on TM, most studies appear to have selected the meditation practices to study on the basis of availability of subjects. Table 1 shows that early field studies used advanced practitioners, while the western studies of the 1970s-1990s usually had meditators with $<5$ years practice. More recent studies have again had access to experienced meditators.

As yet there is no accepted way for researchers to determine meditation proficiency. "Years of meditation practice" has been the primary index of meditation expertise used in meditation research, but this represents only a crude measure of proficiency. The stage of life when the practice was performed may also be relevant as brain structures are more malleable in the formative years. In traditional contemplative practice, a number of meditation practices may be utilized (7), thus attempting to specify the total hours spent in a particular meditation practice is not straightforward.

Unlike other activities such as musical performance or video gaming, which lend themselves to more objective measures such as skill ranking or professional and educational attainment (65), meditation is an internal subjective experience that does not lend itself to external rating. A more accurate proficiency measure, although not so easily obtained, is a rating by the meditator's teacher such as used by Kasamatsu and Hirai (19). 
Ideally studies should encompass a range of meditation proficiency - beginners can show the progressive specificity of the effects of meditation, while experienced meditators are more likely to show distinct changes in states of consciousness (13). Further collaboration between researchers and specific meditation traditions is needed to develop classifications of expertise and levels of training required for proficiency within each tradition.

In contrast to traditionally trained meditators, there is some evidence that western meditators may have a more varied journey through their meditation training, often sampling different teachings before settling within one tradition. A qualitative study of western meditators showed that even within a specific meditation tradition (Kashmir Savism) meditators may undertake a switching back and forth between techniques before adopting a technique suitable for that particular meditation session (Abbott, Ph.D. dissertation, University of Houston, 1996).

The intent of the meditator along with the goals and expectations of the participants in research studies may also be important variables. The same meditation practice, performed as part of a long-standing spiritual practice, e.g., Kasamatsu and Hirai (19) or for an undergraduate project, e.g., Dunn et al. (40) may produce very different states. This issue has received little attention in the literature.

\section{"PRACTICE" VARIABLES}

The aim of meditation state research has often been to distinguish each meditation category by its cognitive processes, which can be linked to associated neurophysiological activity. For example, based on their EEG signatures, Travis and Shear (63) assigned differing meditation practices to particular categories. Yet, as reported in Tables 2-4, the descriptions of the meditation practices provided by most studies are insufficient to enable clear specification of the cognitive tasks involved. Also most studies failed to record or report EEG activity across all frequency bands, undermining the validity of this approach.

An alternative approach suggests that meditation training, regardless of the specific tradition, contains common characteristics and stages of development and that irrespective of the tradition, meditative training involves a similar scheme of development that can be related to distinct EEG signatures (13). In contrast, Lutz et al. (7), while not discounting the possibility that practices from different traditions can have similar effects, contend that it is best to avoid this assumption. Instead they recommend that each meditation tradition's discourse needs to be examined and interpreted to derive descriptions of meditation states that are measureable and repeatable and therefore useful for research. Based on the reviewed studies, it certainly appears that any attempt to link specific meditation practices to EEG signatures is premature and that further progress in this endeavor will require the inclusion of data from the domain of phenomenology.

\section{"PHENOMENOLOGY" VARIABLES}

Tables 2-4 show the few studies that include subjective reports of the meditation states attained, with post-session questionnaires or rating scales being the most used method, e.g., $(28,47)$. Some studies, e.g., (21) and (45) have attempted in-session reporting of subjective states, but as Lo et al. (50) noted, the intrusiveness of these methods renders them impractical during deep meditation.

A potential strategy to improve the accuracy and validity of subjective reports of inner experience is the research approach advocated by Lutz and Thompson (67) in which first-person data from trained subjects is used to guide third-person neurophysiological measurements. Although this approach has not been widely adopted, advanced meditators are seen as providing a more refined first-person description of their experiences (7).

There have been a number of attempts to develop methods for mapping the phenomenology of altered states of consciousness, applicable to meditation practice. Tart (68) argued that the term "altered state of consciousness" has come to be used too loosely. He proposed it to be replaced by a new term; "discrete altered state of consciousness" (d-ASC), described as "unique, dynamic patterns or configurations of psychological structures, active systems of psychological subsystems" (p5). Meditation-induced states of consciousness form a subset of these states (69) explain that Tart's notion of "psychological structures" includes those structures, which regulate the basic parameters of consciousness. These structures are revealed by a recognizable isomorphism (not merely a correlation) between phenomenology and physiology. Thus, a dASC in meditation would be expressed in a discrete state of brain networks, observable as a change in the dominant network of functional connectivity between brain regions, from a defined baseline state.

In a review of a wide range of altered states of consciousness Vaitl et al. (70), used a four dimensional matrix, assessed predominantly on the self-report of the subjects. The dimensions were: "activation" (high to low arousal), "awareness span" (from narrow to broad), "self-awareness" (from heightened to diminished), and "sensory dynamics" (from reduced to heightened sensation). Ott (10) explored the subjective dimensions of "meditation depth" in a sample of yoga, Buddhist, and TM meditators. A factor analysis of 300 questionnaires revealed three dimensions: "mystical experience" - bliss, contact with a higher force, "nirvana" - absence of thought, total absorption, and "mental and bodily relaxation" - reduction of tension.

The dimensions outlined in these two studies can form the foundation for a more detailed analysis of the phenomenological states attained during meditation, expanding the scope beyond the commonly used dimension of attention focus. Meditation practices can be mapped onto these dimensions and subjective reports from meditators used to validate the profile of each practice. Fell et al. (13) describe this process as defining each meditation state of consciousness as a unique area in state space. Exploring neurophysiological signatures of these states can help to answer the question concerning the uniqueness of meditation states of consciousness.

\section{"PSYCHOPHYSIOLOGY" VARIABLES}

Measurement and analysis methods used by meditation state research have changed significantly over the decades, impacting on the interpretation of the brain states being measured. The introduction of neuroimagery techniques, e.g., positron emission tomography (PET), (71) and functional magnetic resonance imagery (fMRI), (72) has greatly extended the ability to 
Table 2 | Studies using focused attention meditation

\begin{tabular}{|c|c|c|c|c|c|c|c|c|c|c|}
\hline \multirow[t]{2}{*}{ Study } & \multicolumn{4}{|c|}{ Practice } & \multicolumn{2}{|c|}{ Phenomenology } & \multicolumn{4}{|c|}{ Psychophysiology - EEG bands } \\
\hline & Practice & Description & Eyes & Focus & Description & $\begin{array}{l}\text { Subjective } \\
\text { report }\end{array}$ & $\theta(4-8 \mathrm{~Hz})$ & $\alpha(8-12 \mathrm{~Hz})$ & $\beta(13-30 \mathrm{~Hz})$ & $\gamma(30-50 \mathrm{~Hz})$ \\
\hline $\begin{array}{l}\text { Kasamatsu and } \\
\text { Hirai (19) Japan }\end{array}$ & Zen & Zazen & Open & NR & $\begin{array}{l}\text { "Concentration } \\
\text { without tension" } \\
\text { "special state of } \\
\text { consciousness" }\end{array}$ & Informal & $\begin{array}{l}\text { Bursts in } \\
\text { advanced }\end{array}$ & $\begin{array}{l}\text { Power increase } \\
\text { freq decrease }\end{array}$ & $\begin{array}{l}\text { Not } \\
\text { measured? }\end{array}$ & Not measured? \\
\hline $\begin{array}{l}\text { Ghista et al. (23) } \\
\text { India }\end{array}$ & $\begin{array}{l}\text { Ananda } \\
\text { Marga }\end{array}$ & $\begin{array}{l}\text { "Intuitional } \\
\text { practice" }\end{array}$ & Closed & $\begin{array}{l}\text { Chakra, } \\
\text { personal } \\
\text { mantra }\end{array}$ & $\begin{array}{l}\text { "Distinct from } \\
\text { mental } \\
\text { concentration" }\end{array}$ & No & $\begin{array}{l}\text { Power } \\
\text { increase }\end{array}$ & $\begin{array}{l}\text { Power increase } \\
\text { freq decrease }\end{array}$ & Not measured & Not measured \\
\hline $\begin{array}{l}\text { Elson et al. (27) } \\
\text { USA }\end{array}$ & $\begin{array}{l}\text { Ananda } \\
\text { Marga }\end{array}$ & & Closed & $\begin{array}{l}\text { Personal } \\
\text { mantra }\end{array}$ & $\begin{array}{l}\text { "Mental } \\
\text { withdrawal and } \\
\text { concentration" }\end{array}$ & No & $\begin{array}{l}\text { Power } \\
\text { increase in } \\
\text { advanced }\end{array}$ & Power increase & Not measured & Not measured \\
\hline $\begin{array}{l}\text { Corby et al. (28) } \\
\text { USA }\end{array}$ & $\begin{array}{l}\text { Ananda } \\
\text { Marga }\end{array}$ & Tantric yoga & Closed & $\begin{array}{l}\text { Personal } \\
\text { mantra, with } \\
\text { breath }\end{array}$ & $\begin{array}{l}\text { "Intense } \\
\text { concentration of } \\
\text { attention" }\end{array}$ & $\begin{array}{l}\text { Meditation } \\
\text { quality rating }\end{array}$ & $\begin{array}{l}\text { Power } \\
\text { increase with } \\
\text { proficiency }\end{array}$ & $\begin{array}{l}\text { Some power } \\
\text { increase }\end{array}$ & Not measured & Not measured \\
\hline $\begin{array}{l}\text { Pan et al. (38) } \\
\text { China }\end{array}$ & Qigong & Concentrative & Closed & $\begin{array}{l}\text { Attention on } \\
\text { breath or } \\
\text { body } \\
\text { sensation }\end{array}$ & $\begin{array}{l}\text { Thinking } \\
\text { regulation }\end{array}$ & No & $\begin{array}{l}\text { Frontal power } \\
\text { increase }\end{array}$ & Power increase & NR & Not measured \\
\hline Kamei (41) Japan & Yoga & $\begin{array}{l}\text { SoHam, } \\
\text { preceded } \\
\text { by asana, } \\
\text { pranayama }\end{array}$ & Closed & $\begin{array}{l}\text { Breath, } \\
\text { mantra }\end{array}$ & NR & No & Not reported & $\begin{array}{l}\text { Power increase } \\
\text { in most S's }\end{array}$ & Not reported & Not reported \\
\hline $\begin{array}{l}\text { Lehmann et al. } \\
\text { (46) Switzerland }\end{array}$ & $\begin{array}{l}\text { Diamond } \\
\text { Way } \\
\text { Buddhist }\end{array}$ & Buddhist & Half closed & $\begin{array}{l}\text { Mantra } \\
\text { Self }\end{array}$ & $\begin{array}{l}\text { Subjectively } \\
\text { different } \\
\text { meditations }\end{array}$ & Informal & Not measured & Not measured & Not measured & $\begin{array}{l}\text { Left central } \\
\text { Right anterior }\end{array}$ \\
\hline $\begin{array}{l}\text { Lo et al. (50) } \\
\text { Taiwan }\end{array}$ & Zen & Inner light & Closed & $\begin{array}{l}\text { Zen and third } \\
\text { eye chakra }\end{array}$ & $\begin{array}{l}\text { Perception of } \\
\text { "inner light" }\end{array}$ & $\begin{array}{l}\text { Signaling of } \\
\text { "inner light" }\end{array}$ & Not reported & $\begin{array}{l}\text { Power increase } \\
\text { in early } \\
\text { meditation }\end{array}$ & $\begin{array}{l}\text { Occurrence on } \\
\text { perception of } \\
\text { "inner light" }\end{array}$ & Not reported \\
\hline
\end{tabular}




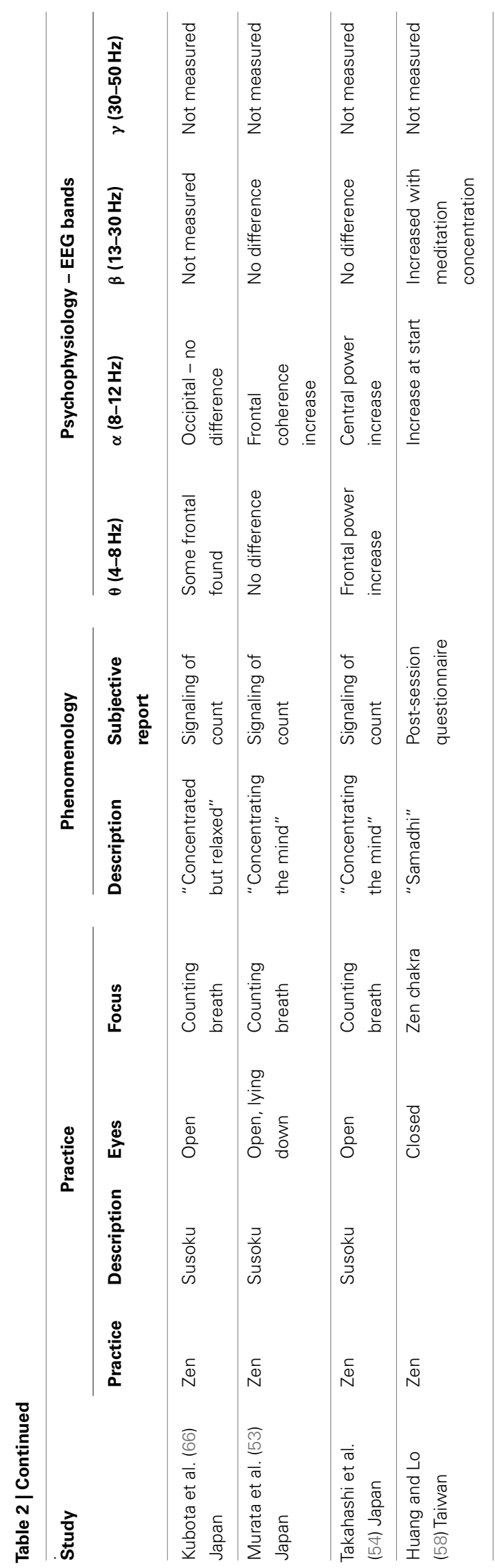

document topographical brain activity and neuronal metabolism activity in various meditation states. However, essentially the same methodological considerations apply as with EEG outcome measures.

\section{TOWARD A STANDARDIZED REPORTING FORMAT FOR MEDITATION STATE RESEARCH}

In order to address the deficiencies in previous research described above, we propose a comprehensive methodological framework for research into meditation states of consciousness to address variables from a broader range of domains.

The first two proposed domains provide the context for the meditation session under study. They are:

- place - the relationship of the study to the cultural origin of the meditation practice and the physical nature of the experimental setting. Variables include; the GPS coordinates of the study location; a description of the setting (laboratory, home, temple, or other facility); the familiarity of the meditator with the setting; the time and date of the data collection, the ambient temperature, barometric pressure, humidity and lighting; the décor including the presence of images, icons, statues, mandalas, yantras, candles, incense, etc.; the proximity to electrical appliances and external electromagnetic fields, the presence of any shielding (Faraday cage), and measures of electromagnetic field strength.

- person - variables relating to the personal history, meditation training, meditation practice, expectations, and motivation of the meditator. This includes; demographic details such as age, gender, ethnicity, socio-economic status, level of education and handedness; health status including the presence or absence of any acute or chronic diseases; anthropometric measures such as height, weight, BMI, head, and waist circumference; current and previous history of use of, or abstinence from, substances such as caffeine, tobacco, alcohol, animal products, and pharmaceutical medicines; details of meditation training including age at commencement of training, type of training, regularity, and duration of practice; the briefing provided prior to the experimental session along with the method of recruitment and personal motivation and expectations of the practitioner. "Person" variables also include measures of personality and temperament such as the Cloninger Temperament and Character Inventory, which has been shown to correlate with meditation performance $(53,54)$.

A further three domains provide the experimental framework within the particular cultural and personal context.

Practice - the actual meditation practice, described in sufficient detail to allow replication. It is suggested that a minimal description of meditation practice should include the specific lineage and tradition that the practice is based on along with any traditional descriptions: posture, eye attitude (open/closed), and how attention is directed.

Phenomenology - the phenomenal state of consciousness produced by the particular meditation practice, as predicted by meditation teachings and the actual experience in the session, validated by feedback from the participants. Further development of 
Table 3 | Studies using open monitoring meditation.

\begin{tabular}{|c|c|c|c|c|c|c|c|c|c|c|}
\hline \multirow[t]{2}{*}{ Study } & \multicolumn{4}{|c|}{ Practice } & \multicolumn{2}{|c|}{ Phenomenology } & \multicolumn{4}{|c|}{ Psychophysiology - EEG bands } \\
\hline & Practice & Description & Eyes & Focus & Description & $\begin{array}{l}\text { Subjective } \\
\text { report }\end{array}$ & $\theta(4-8 \mathrm{~Hz})$ & $\alpha(8-12 \mathrm{~Hz})$ & $\beta(13-30 \mathrm{~Hz})$ & $\gamma(30-50 \mathrm{~Hz})$ \\
\hline $\begin{array}{l}\text { Aftanas and } \\
\text { Golocheikine (47), } \\
\text { Aftanas and } \\
\text { Golocheikine (48, } \\
\text { 49) Siberia }\end{array}$ & Sahaja yoga & & Closed & $\begin{array}{l}\text { Loose, } \\
\text { unfixed } \\
\text { attention }\end{array}$ & $\begin{array}{l}\text { "Thoughtless } \\
\text { awareness and } \\
\text { bliss" }\end{array}$ & $\begin{array}{l}\text { Post-session } \\
\text { questionnaire }\end{array}$ & $\begin{array}{l}\text { Coherence } \\
\text { greater for } \\
\text { LTM, bliss, no } \\
\text { thought }\end{array}$ & Lower power & $\begin{array}{l}\text { Not } \\
\text { measured }\end{array}$ & Not measured \\
\hline $\begin{array}{l}\text { Lutz et al. (51) } \\
\text { USA }\end{array}$ & $\begin{array}{l}\text { Tibetan } \\
\text { Buddhist }\end{array}$ & $\begin{array}{l}\text { "loving- } \\
\text { kindness" }\end{array}$ & Not stated & Open & $\begin{array}{l}\text { "Pure } \\
\text { compassion" }\end{array}$ & No & Not reported & Not reported & $\begin{array}{l}\text { Not } \\
\text { reported }\end{array}$ & $\begin{array}{l}\text { Power } \\
\text { increased }\end{array}$ \\
\hline $\begin{array}{l}\text { Chan et al. (56) } \\
\text { Hong Kong }\end{array}$ & $\begin{array}{l}\text { Triarchic } \\
\text { Body-pathway } \\
\text { Relaxation }\end{array}$ & Mindfulness & Closed & $\begin{array}{l}\text { "Attending to } \\
\text { thoughts and } \\
\text { sensations" }\end{array}$ & $\begin{array}{l}\text { "Deep } \\
\text { relaxation and } \\
\text { internalized } \\
\text { attention" }\end{array}$ & No & $\begin{array}{l}\text { Frontal power } \\
\text { increase }\end{array}$ & $\begin{array}{l}\text { More left } \\
\text { activation }\end{array}$ & $\begin{array}{l}\text { Not } \\
\text { measured }\end{array}$ & Not measured \\
\hline Cahn et al. (60) & Vipassana & $\begin{array}{l}\text { Scanning of } \\
\text { sensations }\end{array}$ & Closed & Open & $\begin{array}{l}\text { "Detached } \\
\text { observation" }\end{array}$ & $\begin{array}{l}\text { Post-session } \\
\text { questionnaire }\end{array}$ & $\begin{array}{l}\text { Decreased } \\
\text { bilateral frontal } \\
\text { delta power. } \\
\text { No theta } \\
\text { effects }\end{array}$ & $\begin{array}{l}\text { Occipital alpha } \\
\text { power } \\
\text { somewhat } \\
\text { related to } \\
\text { expertise }\end{array}$ & $\begin{array}{l}\text { Not } \\
\text { reported }\end{array}$ & $\begin{array}{l}\text { Increase in } \\
\text { parieto- } \\
\text { occipital } \\
\text { gamma }\end{array}$ \\
\hline
\end{tabular}


Table 4 | Studies using transcendental meditation

\begin{tabular}{|c|c|c|c|c|c|c|c|c|c|c|}
\hline \multirow[t]{2}{*}{ Study } & \multicolumn{4}{|c|}{ Practice } & \multicolumn{2}{|c|}{ Phenomenology } & \multicolumn{4}{|c|}{ Psychophysiology - EEG bands } \\
\hline & Practice & Description & Eyes & Focus & Description & $\begin{array}{l}\text { Subjective } \\
\text { report }\end{array}$ & $\theta(4-8 \mathrm{~Hz})$ & $\alpha(8-12 \mathrm{~Hz})$ & $\beta(13-30 \mathrm{~Hz})$ & $\gamma(30-50 \mathrm{~Hz})$ \\
\hline Banquet (21) & TM & Mantra & Closed & Internal & $\begin{array}{l}\text { Relaxed } \\
\text { attention }\end{array}$ & $\begin{array}{l}\text { Push-button } \\
\text { code for five } \\
\text { psychological } \\
\text { states }\end{array}$ & $\begin{array}{l}\text { Second stage: } \\
\text { bursts or trains }\end{array}$ & $\begin{array}{l}\text { First stage: } \\
\text { power increase, } \\
\text { frequency } \\
\text { decrease }\end{array}$ & $\begin{array}{l}\text { Third stage: } \\
\text { rhythmic } \\
\text { waves } \\
\text { correlated } \\
\text { with "deep } \\
\text { meditation" }\end{array}$ & Not reported \\
\hline $\begin{array}{l}\text { Hebert and } \\
\text { Lehmann (25) }\end{array}$ & TM & Mantra & Closed & Internal & $\begin{array}{l}\text { "No } \\
\text { concentration" }\end{array}$ & $\begin{array}{l}\text { Subjective } \\
\text { state reported } \\
\text { when theta } \\
\text { bursts } \\
\text { observed }\end{array}$ & $\begin{array}{l}\text { Frontal bursts } \\
\text { correlated with } \\
\text { "drifting" }\end{array}$ & $\begin{array}{l}\text { Background } \\
\text { activity }\end{array}$ & Occasional & Not reported \\
\hline Morse et al. (3) & $\begin{array}{l}\text { TM, hypnosis, } \\
\text { relaxation }\end{array}$ & $\begin{array}{l}\text { TM mantra } \\
\text { or "one" }\end{array}$ & Closed & Internal & $\begin{array}{l}\text { "Let mind } \\
\text { drift" }\end{array}$ & $\begin{array}{l}\text { States } \\
\text { compared }\end{array}$ & Not reported & $\begin{array}{l}\text { All states } \\
\text { produced } \\
\text { increased } \\
\text { power, negative } \\
\text { correlation with } \\
\text { "depth" }\end{array}$ & $\begin{array}{l}\text { Not } \\
\text { reported }\end{array}$ & Not reported \\
\hline Travis (45) & TM & $\begin{array}{l}\text { Not } \\
\text { described }\end{array}$ & Closed & Internal & $\begin{array}{l}\text { "Transcending" } \\
\text { or "mental and } \\
\text { physical } \\
\text { activity" }\end{array}$ & $\begin{array}{l}\text { Post-session } \\
\text { report at bell } \\
\text { ring } 5 \mathrm{~min} \\
\text { intervals as } \\
\text { "transcend- } \\
\text { ing" or } \\
\text { "other" }\end{array}$ & Not reported & $\begin{array}{l}\text { Higher } \\
\text { amplitude and } \\
\text { coherence with } \\
\text { "transcending" }\end{array}$ & $\begin{array}{l}\text { Not } \\
\text { reported }\end{array}$ & Not reported \\
\hline Hebert et al. (55) & TM & $\begin{array}{l}\text { Not } \\
\text { described }\end{array}$ & Closed & Internal & $\begin{array}{l}\text { "Restful } \\
\text { alertness" }\end{array}$ & Not obtained & Not reported & $\begin{array}{l}\text { Anterior- } \\
\text { posterior phase } \\
\text { synchrony }\end{array}$ & $\begin{array}{l}\text { Not } \\
\text { reported }\end{array}$ & Not reported \\
\hline Travis (62) & TM, TM-Siddhi & $\begin{array}{l}\text { TM: mantra, } \\
\text { general } \\
\text { description } \\
\text { of } \\
\text { TM-Siddhi }\end{array}$ & Closed & Internal & Not obtained & Not obtained & Not reported & $\begin{array}{l}\text { Stronger } \\
\text { sources of } \\
\text { alpha1 in } \\
\text { TM-Siddhi } \\
\text { compared to TM }\end{array}$ & $\begin{array}{l}\text { Not } \\
\text { reported }\end{array}$ & Not reported \\
\hline
\end{tabular}


methods for mapping phenomenological space, building on the work of Vaitl et al. (70) would enable a standardized format to be adopted. Other measures, including "absorption," measured by the Tellegen Absorption Scale also warrant further investigation for usefulness in meditation research (73).

Psychophysiology - adequate documentation of equipment used, methods of collection, analysis, and interpretation of psychophysiological measures. These measures may include: cardiovascular performance, e.g., heart rate, blood pressure, heart rate variability (HRV) (74); brain activity measures, e.g., EEG frequency and low resolution topographical analysis (LORETA) $(46,75)$; and various neuroimaging measures, e.g., MRI to measure cortical thickness (76); Single Photo Emission Computerized Tomography (SPECT) to measure cerebral blood flow (77) and other techniques such as the combined use of EEG (for temporal definition) and fMRI (for spatial definition) (78).

We suggest that the value of this proposed framework would be an improved ability to conduct reproducible research that can accurately position specific meditation states within the total matrix of states of consciousness. By placing the specific relationship of practice-phenomenal state-psycho-physiological measure within the broader context of "place" and "person," the research questions posed in the introduction can be more confidently addressed: do meditation states have specific psycho-physiological characteristics and do meditation states induce specific states of consciousness?

While this approach may lead to more reproducible research and therefore more consistent results, it does not provide specific direction for the formulation of research hypotheses. As the aim of meditation is the experience of mystical higher states of consciousness beyond the thinking mind, it may be that some aspects of meditation are not amenable to rational scientific inquiry and can only be explored through direct personal experience. Nevertheless, it is hoped that the implementation of a consistent approach to reporting research data will advance meditation research and thereby assist in penetrating deeper into the mysteries of human consciousness.

\section{CONCLUSION}

Research to date into meditation states has been inconclusive and is hampered by a number of methodological limitations, primarily the narrow range of variables included in research designs and the lack of inclusion of phenomenological data. Within the context provided by the "place," "person," and "practice," we argue that research will be advanced by a comprehensive program of mapping of phenomenological states to meditation practices and then to psycho-physiological variables. Given this foundation, the questions of uniqueness of meditation states and the specificity of meditation effects may begin to be addressed.

\section{REFERENCES}

1. Cohen MM, Penman S, Pirotta M, Da Costa C. The integration of complementary therapies in Australian general practice: results of a national survey. J Altern Complement Med (2005) 11:995-1004. doi:10.1089/acm.2005.11.995

2. Cahn BR, Polich J. Meditation states and traits: EEG, ERP, and neuroimaging studies. Psychol Bull (2006) 132:180-211. doi:10.1037/0033-2909.132.2.180
3. Morse DR, Martin JS, Furst ML, Dubin LL. A physiological and subjective evaluation of meditation, hypnosis, and relaxation. Psychosom Med (1977) 39:304-24. doi:10.1097/00006842-197709000-00004

4. Shapiro DH Jr. Overview: clinical and physiological comparison of meditation with other self-control strategies. Am J Psychiatry (1982) 139:267-74.

5. Rubia K. The neurobiology of meditation and its clinical effectiveness in psychiatric disorders. Biol Psychol (2009) 82:1-11. doi:10.1016/j.biopsycho.2009. 04.003

6. West MA. Meditation and the EEG. Psychol Med (1980) 10:369-75. doi:10.1017/ S0033291700044147

7. Lutz A, Dunne JD, Davidson RJ. Meditation and the neuroscience of consciousness. In: Zelazo P, editor. Cambridge Handbook of Consciousness. Cambridge: Cambridge University Press (2007). p. 499-554.

8. Ospina MB, Bond K, Karkhaneh M, Tjosvold L, Vandermeer B, Liang Y, et al. Meditation practices for health: state of the research. Evid Rep Technol Assess (Full Rep) (2007) 155:1-263.

9. Bond K, Ospina M, Hooton N, Shannahoff-Khalsa D, Dusek J, Carlson L. Defining a complex intervention: the development of demarcation criteria for "meditation". Psychol Religion Spiritual (2009) 1:129-37. doi:10.1037/a0015736

10. Ott U. The EEG and depth of meditation. J Meditation Med Res (2001) 1:55-68.

11. Lutz A, Slagter HA, Dunne JD, Davidson RJ. Attention regulation and monitoring in meditation. Trends Cogn Sci (2008) 12:163-9. doi:10.1016/j.tics.2008.01. 005

12. Woolfolk RL. Psychophysiological correlates of meditation. Arch Gen Psychiatry (1975) 32(10):1326-33. doi:10.1001/archpsyc.1975.01760280124011

13. Fell J, Axmacher N, Haupt S. From alpha to gamma: electrophysiological correlates of meditation-related states of consciousness. Med Hypotheses (2010) 75:218-24. doi:10.1016/j.mehy.2010.02.025

14. Walsh R. An evolutionary model of meditation research. In: Shapiro D, editor. Meditation: Classic and Contemporary Perspectives. New York: Aldine (1984).

15. Deikman AJ. The state of the art of meditation. In: Shapiro DAW, editor. Meditation: Classic and Contemporary Perspectives. New York: Aldine (1984). p. 679-80.

16. Wenger M, Bagchi B. Studies of autonomic functions in practitioners of yoga in India. Behav Sci (1961) 6:312-23. doi:10.1002/bs.3830060407

17. Das N, Gastaut H. Variations de l'activite electrique du cerveau, du couer et des muscles an cours de la meditation et de l'extrase yogique. Electroceph. Clin. Neurophysiol. Supp (1957) 6:211-9.

18. Anand B. Some aspects of electroencephalographic studies in yogis. Electroencephalogr Clin Neurophysiol (1961) 13:452-6. doi:10.1016/0013-4694(61) 90015-3

19. Kasamatsu A, Hirai T. An electroencephalographic study on the Zen meditation (Zazen). Folia Psychiatr Neurol Jpn (1966) 20:315-36.

20. Wallace RK. Physiological effects of transcendental meditation. Science (1970) 167:1751-4. doi:10.1126/science.167.3926.1751

21. Banquet JP. Spectral analysis of the EEG in meditation. Electroencephalogr Clin Neurophysiol (1973) 35:143-51. doi:10.1016/0013-4694(73)90170-3

22. Pagano RR, Frumkin LR. The effect of transcendental meditation on right hemispheric functioning. Biofeedback Self Regul (1977) 2:407-15. doi:10.1007/ BF00998625

23. Ghista DN, Nandagopal D, Ramamurthi B, Das A, Mukherji A, Srinivasan TM. Physiological characterisation of the 'meditative state' during intuitional practice (the Ananda Marga system of meditation) and its therapeutic value. Med Biol Eng (1976) 14(2):209-13. doi:10.1007/BF02478750

24. Bennett JE, Trinder J. Hemispheric laterality and cognitive style associated with transcendental meditation. Psychophysiology (1977) 14:293-6. doi:10.1111/j. 1469-8986.1977.tb01178.x

25. Hebert R, Lehmann D. Theta bursts: an EEG pattern in normal subjects practising the transcendental meditation technique. Electroencephalogr Clin Neurophysiol (1977) 42:397-405. doi:10.1016/0013-4694(77)90176-6

26. Fenwick P, Donaldson S, Gillis L, Bushman J, Fenton G, Perry I, et al. Metabolic and EEG changes during transcendental meditation: an explanation. Biol Psychol (1977) 5:101-18. doi:10.1016/0301-0511(77)90007-2

27. Elson BD, Hauri P, Cunis D. Physiological changes in yoga meditation. Psychophysiology (1977) 14:52-7. doi:10.1111/j.1469-8986.1977.tb01155.x

28. Corby JC, Roth WT, Zarcone VP Jr., Kopell BS. Psychophysiological correlates of the practice of Tantric yoga meditation. Arch Gen Psychiatry (1978) 35:571-7. doi:10.1001/archpsyc.1978.01770290053005 
29. Lehrer PM, Woolfolk RL, Rooney AJ, McCann B, Carrington P. Progressive relaxation and meditation. A study of psychophysiological and therapeutic differences between two techniques. Behav Res Ther (1983) 21:651-62. doi:10.1016/0005-7967(83)90083-9

30. Stigsby B, Rodenberg JC, Moth HB. Electroencephalographic findings during mantra meditation (transcendental meditation). A controlled, quantitative study of experienced meditators. Electroencephalogr Clin Neurophysiol (1981) 51:434-42. doi:10.1016/0013-4694(81)90107-3

31. Becker DE, Shapiro D. Physiological responses to clicks during zen, yoga, and TM meditation. Psychophysiology (1981) 18:694-9. doi:10.1111/j.1469-8986.1981. tb01846.x

32. Dillbeck MC, Bronson EC. Short-term longitudinal effects of the transcendental meditation technique on EEG power and coherence. Int J Neurosci (1981) 14:147-51. doi:10.3109/00207458108985827

33. Farrow J, Hebert J. Breath suspension during the transcendental meditation technique. Psychosomatic Medicine (1982) 44:133-53.

34. Badawi K, Wallace RK, Orme-Johnson D, Rouzere A. Electrophysiologic characteristics of respiratory suspension periods occurring during the practice of TM program. Psychosom Med (1984) 46:267. doi:10.1097/00006842-19840500000008

35. Zhang J-Z, Jing Z, He Q-N. EEG findings during special psychical state (Qigong state) by means of compressed spectral array and topograhical mapping. Comput Biol Med (1988) 18:455-63. doi:10.1016/0010-4825(88)90063-7

36. Gaylord C, Orme-Johnson D, Travis F. The effects of the transcendental mediation technique and progressive muscle relaxation on EEG coherence, stress reactivity, and mental health in black adults. Int J Neurosci (1989) 46:77-86. doi:10.3109/00207458908991618

37. Benson H, Malhotra MS, Goldman RF, Jacobs GD, Hopkins PJ. Three case reports of the metabolic and electroencephalographic changes during advanced Buddhist meditation techniques. Behav Med (1990) 16:90-5. doi:10.1080/ 08964289.1990.9934596

38. Pan W, Zhang L, Xia Y. The difference in EEG theta waves between concentrative and non-concentrative qigong states - a power spectrum and topographic mapping study. J Tradit Chin Med (1994) 14:212-8.

39. Travis F, Wallace RK. Autonomic and EEG patterns during eyes-closed rest and transcendental meditation (TM) practice: the basis for a neural model of TM practice. Conscious Cogn (1999) 8:302-18. doi:10.1006/ccog.1999.0403

40. Dunn BR, Hartigan JA, Mikulas WL. Concentration and mindfulness meditations: unique forms of consciousness? Appl Psychophysiol Biofeedback (1999) 24:147-65. doi:10.1023/A:1023498629385

41. Kamei T. Decrease in serum cortisol during yoga exercise is correlated with alpha wave activity. Percept Mot Skills (2000) 90:1027-32. doi:10.2466/pms.2000.90.3 1027

42. Khare KC, Nigam SK. A study of electroencephalogram in meditators. Indian J Physiol Pharmacol (2000) 44:173-8.

43. Arambula P, Peper E, Kawakami M, Gibney KH. The physiological correlates of Kundalini yoga meditation: a study of a yoga master. Appl Psychophysiol Biofeedback (2001) 26:147-53. doi:10.1023/A:1011343307783

44. Litscher G, Wenzel G, Niederwieser G, Schwarz G. Effects of QiGong on brain function. Neurol Res (2001) 23:501-5. doi:10.1179/016164101101198749

45. Travis F. Autonomic and EEG patterns distinguish transcending from other experiences during Transcendental Meditation practice. Int J Psychophysiol (2001) 42:1-9. doi:10.1016/S0167-8760(01)00143-X

46. Lehmann D, Faber PL, Achermann P, Jeanmonod D, Gianotti LRR, Pizzagalli D. Brain sources of EEG gamma frequency during volitionally meditation-induced, altered states of consciousness, and experience of the self. Psychiatry Res Neuroimaging (2001) 108:111-21. doi:10.1016/S0925-4927(01) 00116-0

47. Aftanas LI, Golocheikine SA. Human anterior and frontal midline theta and lower alpha reflect emotionally positive state and internalized attention: highresolution EEG investigation of meditation. Neurosci Lett (2001) 310:57-60. doi:10.1016/S0304-3940(01)02094-8

48. Aftanas LI, Golocheikine SA. Non-linear complexity of the human EEG during meditation. Neurosci Lett (2002) 330(2):143-6. doi:10.1016/S0304-3940(02) 00745-0

49. Aftanas LI, Golocheikine SA. Changes in cortical activity during altered states of consciousness: study of meditation by high resolution EEG. Hum Physiol (2003) 29(2):143-51. doi:10.1023/A:1022986308931
50. Lo PC, Huang ML, Chang KM. EEG alpha blocking correlated with perception of inner light during Zen meditation. Am J Chin Med (2003) 31:629-42. doi:10.1142/S0192415X03001272

51. Lutz A, Greischar LL, Rawlings NB, Ricard M, Davidson RJ. Long-term meditators self-induce high-amplitude gamma synchrony during mental practice. Proc Natl Acad Sci U S A (2004) 101:16369-73. doi:10.1073/pnas. 0407401101

52. Faber PL. Scalp and Intracerebral (LORETA) Theta and Gamma EEG Coherence in Meditation. Winterhur: European Chapter of Int. Soc Neuronal Regulation (2004).

53. Murata T, Takahashi T, Hamada T, Omori M, Kosaka H, Yoshida H, et al. Individual trait anxiety levels characterizing the properties of zen meditation. Neuropsychobiology (2004) 50:189-94. doi:10.1159/000079113

54. Takahashi T, Murata T, Hamada T, Omori M, Kosaka H, Kikuchi M, et al. Changes in EEG and autonomic nervous activity during meditation and their association with personality traits. Int J Psychophysiol (2005) 55:199-207. doi:10.1016/j.ijpsycho.2004.07.004

55. Hebert R, Lehmann D, Tan G, Travis F, Arenander A. Enhanced EEG alpha time-domain phase synchrony during transcendental meditation: implications for cortical integration theory. Signal Processing (2005) 85:2213-32. doi:10.1016/j.sigpro.2005.07.009

56. Chan AS, Han YM, Cheung MC. Electroencephalographic (EEG) measurements of mindfulness-based Triarchic body-pathway relaxation technique: a pilo study. Appl Psychophysiol Biofeedback (2008) 33:39-47. doi:10.1007/s10484008-9050-5

57. Beauregard M, Paquette V. EEG activity in Carmelite nuns during a mystical experience. Neurosci Lett (2008) 444:1-4. doi:10.1016/j.neulet.2008.08.028

58. Huang H-Y, Lo P-C. EEG dynamics of experienced Zen meditation practitioners probed by complexity index and spectral measure. J Med Eng Technol (2009) 33:314-21. doi:10.1080/03091900802602677

59. Lagopoulos J, Xu J, Rasmussen I, Vik A, Malhi GS, Eliassen CF, et al. Increased theta and alpha EEG activity during nondirective meditation. J Altern Complement Med (2009) 15:1187-92. doi:10.1089/acm.2009.0113

60. Cahn BR, Delorme A, Polich J. Occipital gamma activation during Vipassana meditation. Cogn Process (2010) 11:39-56. doi:10.1007/s10339-0090352-1

61. Lehmann D, Faber PL, Tei S, Pascual-Marqui RD, Milz P, Kochi K. Reduced functional connectivity between cortical sources in five meditation traditions detected with lagged coherence using EEG tomography. Neuroimage (2012) 60:1574-86. doi:10.1016/j.neuroimage.2012.01.042

62. Travis F. Comparison of coherence, amplitude, and eLORETA patterns during Transcendental Meditation and TM-Sidhi practice. Int J Psychophysiol (2011) 81:198-202. doi:10.1016/j.ijpsycho.2011.06.011

63. Travis F, Shear J. Focused attention, open monitoring and automatic transcending: categories to organise meditations from Vedic, Buddhist and Chinese traditions. Conscious Cogn (2010) 19(4):1110-8. doi:10.1016/j.concog.2010.01.007

64. Tart C. States of Consciousness. New York: E.P. Dutton (1975).

65. Latham A, Patston LL, Tippett LJ. Just how expert are "expert" video-game players? Assessing the experience and expertise of video-game players across “action” video-game genres. Front Psychol (2013) 4:941. doi:10.3389/fpsyg.2013. 00941

66. Kubota Y, Sato W, Toichi M, Murai T, Okada T, Hayashi A. Frontal midline theta rhythm is correlated with cardiac autonomic activities during the performance of an attention demanding meditation procedure. Brain Res Cogn Brain Res (2001) 11(2):281-7.

67. Lutz A, Thompson E. Neurophenomenology: integrating subjective experience and brain dynamics in the neuroscience of consciousness. J Conscious Stud (2003) 10:31-52.

68. Tart CT. States of Consciousness. Lincoln: iUniverse.com Inc (2000). [Original work published 1983].

69. Jamieson G, Hasegawa H. New paradigms of hypnosis research. In: Jamieson G, editor. Hypnosis and Conscious States: The Cognitive Neuroscience Perspective. Oxford: Oxford University Press (2007). p. 133-44.

70. Vaitl D, Gruzelier J, Jamieson G, Lehmann D, Ott U, Sammer G, et al. Psychobiology of altered states of consciousness. Psych Bull (2005) 131:98-127. doi:10.1037/0033-2909.131.1.98

71. Lou HC, Kjaer TW, Friberg L, Wildschiodtz G, Holm S, Nowak M. A 15O$\mathrm{H} 2 \mathrm{O}$ PET study of meditation and the resting state of normal consciousness. 
Hum Brain Mapp (1999) 7:98-105. doi:10.1002/(SICI)1097-0193(1999)7:2<98: :AID-HBM3>3.3.CO;2-D

72. Hölzel BK, Ott U, Hempel H, Hackl A, Wolf K, Stark R, et al. Differential engagement of anterior cingulate and adjacent medial frontal cortex in adept meditators and non-meditators. Neurosci Lett (2007) 421:16-21. doi:10.1016/j.neulet. 2007.04.074

73. Jamieson G. The Modified Tellegen Absorption Scale: a clearer window on the structure and meaning of absorption. Aust J Clin Exp Hypn (2005) 33:119-39.

74. Krygier JR, Heathers JA, Shahrestani S, Abbott M, Gross JJ, Kemp AH. Mindfulness meditation, well-being and heart rate variability: a preliminary investigation into the impact of intensive Vipassana meditation. Int J Psychophysiol (2013) 89:305-13. doi:10.1016/j.ijpsycho.2013.06.017

75. Travis F, Haaga D, Hagelin J. A self-referential default brain state: patterns of coherence, power and eLORETA sources during eyes-closed rest and Transcendental Meditation. Cogn Process (2010) 11:21-30. doi:10.1007/s10339009-0343-2

76. Grant JA, Duerden EG, Courtemanche J, Cherkasova M, Duncan GH, Rainville P. Cortical thickness, mental absorption and meditative practice: possible implications for disorders of attention. Biol Psychol (2013) 92:275-81. doi:10.1016/j. biopsycho.2012.09.007

77. Newberg A, Alavi A, Baime M, Pourdehnad M, Santanna J, d'Aquili E. The measurement of regional cerebral blood flow during the complex cognitive task of meditation: a preliminary SPECT study. Psychiatry Res (2001) 106:113-22. doi:10.1016/S0925-4927(01)00074-9

78. Beauregard M, Courtemanche J, Paquette V. Brain activity in near-death experiencers during a meditative state. Resuscitation (2009) 80:1006-10. doi:10.1016/ j.resuscitation.2009.05.006

Conflict of Interest Statement: The authors declare that the research was conducted in the absence of any commercial or financial relationships that could be construed as a potential conflict of interest.

Received: 15 December 2013; paper pending published: 31 March 2014; accepted: 13 June 2014; published online: 01 July 2014.

Citation: Thomas JW and Cohen M (2014) A methodological review of meditation research. Front. Psychiatry 5:74. doi: 10.3389/fpsyt.2014.00074

This article was submitted to Affective Disorders and Psychosomatic Research, a section of the journal Frontiers in Psychiatry.

Copyright $(2014$ Thomas and Cohen. This is an open-access article distributed under the terms of the Creative Commons Attribution License (CC BY). The use, distribution or reproduction in other forums is permitted, provided the original author(s) or licensor are credited and that the original publication in this journal is cited, in accordance with accepted academic practice. No use, distribution or reproduction is permitted which does not comply with these terms. 